\title{
A Disease Must Be Considered in the Differential Diagnosis of Ascites: Familial Mediterranean Fever
}

\author{
Mehmet Bektaş ${ }^{\mathrm{a}} \quad$ Mehmet Altan $^{\mathrm{a}}$ Sim Kutlay ${ }^{\mathrm{b}}$ Deniz Gören ${ }^{\mathrm{a}}$ İrfan Soykan ${ }^{\mathrm{a}}$ \\ Esin Korkut $^{\mathrm{a}}$ Hülya Çetinkaya ${ }^{\mathrm{a}}$ Ali Özden ${ }^{\mathrm{a}}$ \\ Departments of ${ }^{\mathrm{a}}$ Gastroenterology and ${ }^{\mathrm{b}}$ Nephrology, School of Medicine, Ankara University, Ankara, Turkey
}

Dear Sir,

Familial Mediterranean fever (FMF) is an autosomal recessive disease which most commonly occurs in Sephardic Jews, Armenians, Arabs and Turks. FMF is characterized by recurrent and self-limited attacks of fever accompanied by peritonitis, pleuritis, sinovitis or erysipelas-like erythema $[1,2]$. Inflammation of all serosal membranes can be seen during attacks, such as pleuritis, sinovitis and pericarditis. Small amounts of peritoneal fluid are often seen at laparoscopy of FMF patients. This finding reflects a peritoneal reaction to repetitive inflammation, which is a process that in extreme cases may develop into ascites [3]. Ascites with large amounts of peritoneal fluid is an uncommon manifestation of FMF. In this report we present 5 FMF patients with recurrent ascites.

\section{Case Reports}

Five female patients were admitted to our clinic between 2002 and 2004 with ascites of unknown etiology. In all of the cas- es ascites were detected on physical examination. We could not detect any clinical or laboratory signs of benign (heart, liver, kidney and gynecological diseases and tuberculosis) or malignant disorders. The laboratory test results are displayed in table 1. Serum-ascites albumin gradients were found $>1.1$ in 2 cases. Liver biopsy was performed in case 1 and reported as reactive changes. The cell counts in the ascites samples were $\leq 250 / \mathrm{mm}^{3}$. The results of ascites assessments are displayed in table 2. However, all of the patients have had

Table 1. Characteristics of patients

\begin{tabular}{|c|c|c|c|c|c|}
\hline Characteristic & Case 1 & Case 2 & Case 3 & Case 4 & Case 5 \\
\hline Sex & $\mathrm{F}$ & $\mathrm{F}$ & $\mathrm{F}$ & $\mathrm{F}$ & $\mathrm{F}$ \\
\hline Age, years & 34 & 25 & 26 & 17 & 56 \\
\hline Time of ascites & 2 years & 4 years & 2 months & 1 month & 8 years \\
\hline Time of FMF & new & 6 years & 15 years & 7 years & new \\
\hline Family history of FMF & yes & yes & yes & yes & no \\
\hline Proteinuria & negative & negative & negative & negative & negative \\
\hline Sedimentation (normal $0-20$ ), $\mathrm{mm} / \mathrm{h}$ & 13 & 7 & 25 & 29 & 30 \\
\hline CRP (normal 0-3), mg/dl & 8.68 & 3.2 & 16.3 & 4.49 & 3 \\
\hline Abdominopelvic CT & manifest ascites & pelvic ascites & $\begin{array}{l}\text { hydrosalpinx, } \\
\text { pelvic ascites }\end{array}$ & $\begin{array}{l}\text { minimal pelvic } \\
\text { ascites }\end{array}$ & pelvic ascites \\
\hline Amyloidosis (rectum biopsy) & negative & negative & negative & negative & positive \\
\hline Mutation analysis & M694V/V726A & M694V/V726A & M694V/M694V & M694/? & M694V/M694V \\
\hline Colchium response & unknown & yes & yes & yes & yes \\
\hline
\end{tabular}

\section{KARGER}

Fax +41 613061234 E-Mail karger@karger.ch www.karger.com
Dr. Mehmet Bekta

Ankara University, School of Medicine

Department of Gastroenterology, Tip Fakultesi Hastanesi

TR-06100 Dikimevi, Ankara (Turkey)

Tel. +90 312595 6899, Fax +90 312363 6213, E-Mail mbektas@medicine.ankara.edu.tr 
Table 2. Results of ascites fluid examination

\begin{tabular}{llllll}
\hline Characteristic & Case 1 & Case 2 & Case 3 & Case 4 & Case 5 \\
\hline Color & yellow & yellow & clear & clear & clear \\
White blood cell count, cells/mm & 100 & 120 & 250 & 200 & 40 \\
Albumin (normal 3.5-6.2), g/dl & 2.6 & 3.5 & 2.6 & 2.9 & 2.1 \\
Serum-ascites albumin gradient $(\leq 1.1)$ & 0.6 & 0.5 & 1.3 & 1.5 & 1.6 \\
Glucose (normal 74-106), $\mathrm{mg} / \mathrm{dl}$ & 103 & 79 & 75 & 138 & 71 \\
LDH (normal 240-480), U/l & 125 & 115 & 105 & negative & negative \\
Culture & negative & negative & negative & benign & benign \\
Cytology & benign & benign & benign & 12.5 & 21.9 \\
Adenosine deaminase $(<30), \mathrm{IU} / \mathrm{ml}$ & 15.3 & 11.6 & 19.9 & negative & negative \\
Acid-resistant bacile staining & negative & negative & negative & &
\end{tabular}

Table 3. Patients' clinical features based on Tel Hashomer criteria

\begin{tabular}{|c|c|c|c|c|c|}
\hline & Case 1 & Case 2 & Case 3 & Case 4 & Case 5 \\
\hline \multicolumn{6}{|l|}{ Major criteria } \\
\hline $\begin{array}{l}\text { Recurrent febrile episodes accompanied by peritonitis, } \\
\text { synovitis or pleuritis }\end{array}$ & + & + & + & + & + \\
\hline Amyloidosis of the AA type without predisposing disease & - & - & - & - & + \\
\hline Favorable response to continuous colchicine treatment & - & + & + & + & + \\
\hline \multicolumn{6}{|l|}{ Minor criteria } \\
\hline Recurrent febrile episodes & + & + & + & + & + \\
\hline Erysipelas-like erythema & - & - & - & - & - \\
\hline FMF in a first-degree relative & + & + & + & + & - \\
\hline
\end{tabular}

complaints of episodic abdominal pain with fever lasting 1-2 days since their childhood. Some of these patients had previously received colchicine treatment in other clinics for suspected FMF diagnosis. They had reported discontinued colchicine use on their own will, after taking the drug for different periods. The clinical features based on Tel Hashomer criteria are displayed in table 3. Genetic tests of these 5 cases revealed that 2 were homozygote for M694V/M694V, 2 were compound heterozygote for M694V/726 and 1 case was heterozygote for $\mathrm{M} 694 \mathrm{~V} /$ ? gene mutations. Each patient received colchicine treatment at a dose of $0.5 \mathrm{mg}$ per $8 \mathrm{~h}$, and at the end of an average of 6 months of treatment, ascites were resolved in cases 2-5, as opposed to case 1 , and this patient had therapeutic parasynthesis twice, followed by laparoscopic examination. During laparoscopy, 5 liters of ascites was drained, and perito- neal biopsy was taken, which helped rule out tuberculosis and malignancy, and the histological examination of the specimen was well adjusted with chronic peritonitis. During the follow-up period of case 1, colchicine was continued after laparoscopy, and no further ascites collection was observed.

\section{Discussion}

In FMF, peritoneal effusion during abdominal attacks is usually mild, is not detected by clinical evaluation and disappears during clinical remission. Chronic ascites has rarely been described in patients with FMF $[1,4,5]$. Small amounts of peritoneal fluid are often seen at laparoscopy or at radiological imaging techniques such as ultrasonography or CT of FMF patients [6]. Colchicine is the most effective treatment to control FMF attacks. In the medical literature, 3 patients with ascites have been reported, who received colchicine, and in 2 of whom the ascites resolved on follow-up, while the third had an encapsulated peritonitis and unresolving ascites that remitted with short-term corticosteroids, but relapsed when the dose was reduced, and finally was treated surgically $[5,7]$. In our study, each patient received colchicine treatment and at the end of an average of 6 months of treatment, the ascites were resolved in the cases.

In conclusion, ascites may develop in FMF patients due to chronic peritoneal irritation. Colchicine treatment may help resolve the ascites. In countries like Turkey, where FMF is more frequently encountered, this disease must be considered in the differential diagnosis of ascites. 
-1 Sohar E, Gafni J, Pras M, Heller H: Familial Medirerranean fever: a survey of 470 cases and reviews of literature. Am J Med 1967;43: 227-253.

-2 Grateau G, Pecheux C, Cazeneuve C, Cattan D, Dervichian M, Goossens M, Delpech M, Amselem S, Dode C: Clinical versus genetic diagnosis of familial Mediterranean fever. QJM 2000;93:223-229.
-3 Bellin MF, Deutsch JP, Bletry O, Langlois P, Bousquet JC, Cortez A, Godeau P, Grellet J: Encapsulating peritonitis in periodic disease: apropos of a case studied by X-ray computed tomography (abstract). Ann Radiol (Paris) 1989;32:302-304.

4 Mor A, Gal R, Livneh A: Abdominal and digestive system associations of Famillial Mediterranen fever. Am J Gastroenterol 2003;98:2594-2604.

5 Cekin AH, Dalbudak N, Kunefeci G, Gur G, Boyacioglu S: Familial Mediterranean fever with massive recurrent ascites: a case report. Turk J Gastroenterol 2003;14:276-279.
6 Zissin R, Rathaus V, Gayer G, Shapiro-Feinberg M, Hertz M: CT findings in patients with familial Mediterranean fever during an acute abdominal attack. Br J Radiol 2003;76: 22-25.

7 Lelievre JD, Ranque-Francois B, AslangulCastier E, Adle-Biassette H, Papo T: Chronic ascites related to encapsulating peritonitis in familial Mediterranean fever. Am J Med 2002;113:80-81. 